\title{
Production and Breeding of Transgenic Cloned Pigs Expressing Human CD73
}

\author{
Seung-Chan Lee, Haesun Lee, Keon Bong Oh, In-Sul Hwang, Hyeon Yang, Mi-Ryung Park, \\ Sun-A Ock, Jae-Seok Woo, Gi-Sun Im and †Seongsoo Hwang \\ Animal Biotechnology Division, National Institute of Animal Science, RDA, Wanju 55365, Republic of Korea
}

\begin{abstract}
One of the reasons to causing blood coagulation in the tissue of xenografted organs was known to incompatibility of the blood coagulation and anti-coagulation regulatory system between TG pigs and primates. Thus, overexpression of human $\mathrm{CD} 73$ (hCD73) in the pig endothelial cells is considered as a method to reduce coagulopathy after pig-to-non-humanprimate xenotransplantation. This study was performed to produce and breed transgenic pigs expressing hCD73 for the studies immune rejection responses and could provide a successful application of xenotransplantation. The transgenic cells were constructed an hCD73 expression vector under control porcine Icam2 promoter (pIcam2-hCD73) and established donor cell lines expressing hCD73. The numbers of transferred reconstructed embryos were $127 \pm 18.9$. The pregnancy and delivery rate of surrogates were $8 / 18(44 \%)$ and 3/18 (16\%). The total number of delivered cloned pigs were 10 ( 2 alive, 7 mummy, and 1 died after birth). Among them, three live hCD73-pigs were successfully delivered by Caesarean section, but one was dead after birth. The two hCD73 TG cloned pigs had normal reproductive ability. They mated with wild type (WT) MGH (Massachusetts General Hospital) female sows and produced totally 16 piglets. Among them, 5 piglets were identified as hCD73 TG pigs. In conclusion, we successfully generated the hCD73 transgenic cloned pigs and produced their litters by natural mating. It can be possible to use a mate for the production of multiple transgenic pigs such as $\alpha$-1,3-galactosyltransferase knock-out /hCD46 for xenotransplantation.
\end{abstract}

Key words : hCD73, Porcine Icam2 promoter, Coagulation, Transgenic cloned pig, Xenotransplantation

\section{INTRODUCTION}

Xenotransplantation of organs from pigs into humans has been considered as a promising solution for shortage of organs, because of their physiological and anatomical similarities. Recently, a significant progress has been made in that cardiac xenograft from the $\alpha$-1,3-galactosyltransferase knock-out (GT KO) pigs with human complement regulatory protein and human thrombomodulin molecules to baboons survived for over 900 days (Mohiuddin et al.,
2016) and renal xenotransplantation extended over 227 days with GT KO/CD55 (decay accelerating factor; DAF) transgenic pig-to-macaque (Higginbotham et al., 2015). However, except these successful reports, many xenograft cases have been suffered from various immune rejections. To minimize immune rejection phenomenon after TG pigto-primate xenotransplantation, GT KO pigs with an overexpression of and simultaneous inhibition of human complement activation by the introduction of human complement-regulatory genes, such as CD46 (membrane cofactor

\footnotetext{
Manuscript received May 1, 2017, Received in revised form May 4, 2017, Accepted May 8, 2017

$\dagger$ Corresponding Author: Seongsoo Hwang, Animal Biotechnology Division, National Institute of Animal Science, RDA 1500, Wanju 55365, Republic of Korea, Tel: +82-63-238-7253; Fax: +82-63-238-7297, E-mail: hwangss@korea.kr

This is an Open Access article distributed under the terms of the Creative Commons Attribution Non-Commercial License (http:// creativecommons.org/licenses/by-nc/3.0) which permits unrestricted non-commercial use, distribution, and reproduction in any medium, provided the original work is properly cited.
} 
protein, MCP), CD55 (Lee et al., 2011), and CD59 (Lambrigts et al. 1998; McGregor et al. 2004).

The previous studies have demonstrated that thrombotic microangiopathy had been occurred in primates following xenotransplantation with GT KO pig solid organs without hyperacute immune rejection causing galactose- $\alpha$ 1,3-galactose antigens ( $\alpha$-Gal) (Houser et al., 2004; Kuwaki et al., 2005; Tseng et al., 2005; Shimizu et al., 2008, Kim et al., 2013). Major features of thrombotic microangiopathy such as platelet activation, adherence, and clumping were inevitable consequences of immune-mediated transplant rejection (Rocha et al., 2003; Zhang et al., 2008). Thus, a disordered thromboregulation represents major immunological obstacles to long-term survival of xenoorgans. One of the reasons to causing blood coagulation in the tissue of xenografted organs was known to incompatibility of the blood coagulation and anti-coagulation regulatory system between TG pigs and primates (Cowan and d'Apice, 2009; Lin et al., 2009; Ekser et al., 2012).

Extracellular nucleotides (adenosine triphosphate; ATP and adenosine diphosphate; ADP) regulate thrombosis and inflammatory responses. ATP and ADP are converted to adenosine monophosphate (AMP) by CD39 (ectonucleoside triphosphate diphosphohydrolase 1; ENTPDase-1), which is catalyzed to adenosine by CD73 (ecto-5'-nucleotidase; e5NT) (Crikis et al., 2006). Decreasing of CD73 activity leads to reduce adenosine production and to decrease expression of cytoprotective factors and disordered blood coagulation control (Daval et al., 1991; Delikouras et al., 2003; Sitkovsky et al., 2004). In fact, pig endothelial cells in heart have significantly lower levels of CD73 compared with those of humans, resulting in decreased adenosine production in blood (Khalpey et al., 2005). For this reason, transplantation of GT KO pig organs expressing human CD39 and CD73 into the primates is expected to inhibit the inflammation reaction and blood coagulation (Cooper et al., 2012).

In our previous study, we constructed a human CD73 expression vector under control of porcine Icam2 promoter (pIcam2-hCD73) and established forty three donor cell lines expressing hCD73 (Oh et al., 2016). This study was performed to produce and breed transgenic pigs expressing hCD73.

\section{MATERIALS AND METHODS}

\section{General information}

Our study protocol and standard operating procedures for the treatments of the pigs used were reviewed and approved by the Institutional Animal Care and Use Committee of the National Institute of Animal Science, RDA (Approval number: NIAS2016-199, D-grade).

\section{Construction of the vector for hCD73 expression}

Our procedure for vector construction was previously described in detail (Oh et al., 2016). Briefly, the human CD73 cDNA clone was purchased from 21C Frontier Human Gene Bank (Korea, Clone ID, Hmu001092). The gene was synthesized by PCR using PrimeSTAR ${ }^{\mathrm{TM}}$ HS DNA polymerase (Takara Bio Inc, Shiga, Japan). That was amplified using upstream primer 5'-ATGCGGCCGCTTTCG CACCCAGTTCAC-3' and downstream primer 5'-AATCT CTCGAGCTATTGGTATAAAACAAAG-3', each of which has the restrict enzyme sites Not I and Xho I at the end of the sequence, respectively. The porcine Icam 2 promoter was isolated by PCR from the template genomic DNA extracted from porcine ear tissue. The primers used for PCR were 5'-TATCGCGATCTAGAAACACACTGCAAG TCC-3' and 5'-ATAAGCTTAGGAAAGAGCCGAGGAC CGCCT-3' which contain Nru I and Hind III site, respectively. The pCMV-hCD73 vector was constructed by cloning the NotI and Xho I fragment of synthesized CD73 cDNA into pcDNA3.1 hygro vector. To generate another form of pIcam2-CD73 vector, the pCMV-hCD73 vector was digested into two segment using Nru I and Hind III, and then removed the CMV promoter. The Nru I and Hind 
III fragment of Icam2 promoter was inserted into the Nru I and Hind III site of hCD73 expression vector.

\section{Establishment of hCD73 transgenic donor cell lines}

To introduce the exogenous DNA into the porcine endothelial cells originated from the main artery of 3-week-old male MGH (Massachusetts General Hospital) minipigs (generously donated by Dr. David H. Sachs, Transplantation Biology Research Center, Massachusetts General Hospital, Boston, Massachusetts 02129, USA), nucleofection was performed using primary mammalian endothelial cells, Amaxa Basic Nucleofector ${ }^{\circledR}$ Kit (Lonza). 48 hours after nucleofection, the cells were incubated in the medium contained $400 \mathrm{mg} / \mathrm{mL}$ of hygromycin. For the gene analysis of the clones selected by the hygromycin resistances, some of the cells were lysed for 2 hours at $55^{\circ} \mathrm{C}$ with solution consistent of $50 \mathrm{mM} \mathrm{KCl}, 10 \mathrm{mM}$ Tris- $\mathrm{HCl}$ [pH 8.3], $2 \mathrm{mM} \mathrm{MgCl}_{2}, 0.45 \%(\mathrm{v} / \mathrm{v})$ NP-40, 0.5\%(v/v) Tween 20, and $100 \mathrm{mg} / \mathrm{mL}$ of proteinase $\mathrm{K}$. The insertion of pCMVhCD73 vector was detected by PCR with upstream primer 5'-CTATTGACGTCAATGACGGTA-3' and downstream primer 5'-CAAAACCCGAATGTCCCAGTGCAA-3'. To confirm the integration of pIcam2-CD73 vector into the endogenous genomic DNA, the gene was amplified by upstream primer 5'-ACTTAGTCATGGTGACTGCATGCC$3^{\prime}$ and the downstream primer which was same as previous one. The amplification conditions were as follows: initial denaturation at $94^{\circ} \mathrm{C}$ for $5 \mathrm{~min}, 35$ repetitions at $94^{\circ} \mathrm{C}$ for $30 \mathrm{~s}$, annealing at $60^{\circ} \mathrm{C}$ for $30 \mathrm{~s}$, extension at $72^{\circ} \mathrm{C}$ for $1 \mathrm{~min}$ $30 \mathrm{~s}$, and then final extension step at $72{ }^{\circ} \mathrm{C}$ for $7 \mathrm{~min}$. The amplified product size was $1 \mathrm{~kb}$. After the confirmation, the transgenic donor cells were cultured in Dulbecco's modified Eagle medium (WelGene Inc., Korea) containing $20 \%$ FBS, $1 \mathrm{mM}$ of non-essential amino acid (GIBCO), 1 $\mathrm{mM}$ of sodium pyruvate (WelGene, Korea), $55 \mu \mathrm{M}$ of $\beta$ mercaptoethanol (GIBCO), and 1\% antibiotics $(100 \mathrm{U} / \mathrm{mL}$ penicillin and $100 \mu \mathrm{g} / \mathrm{mL}$ streptomycin; GIBCO) at $37^{\circ} \mathrm{C}$ in an atmosphere of $5 \% \mathrm{CO}_{2}$ in air and cryopreserved into $\mathrm{LN}_{2}$ until use.

\section{Production of reconstructed embryos and cloned} piglets

In vitro maturation of porcine immature follicular oocytes was performed as follows with slight modifications (Hwang et al., 2015). Porcine ovaries were obtained from a local slaughterhouse (Nonghyup Moguchon, Gimje, South Korea) and transported to the laboratory at $30-35^{\circ} \mathrm{C}$. Cumulus-oocyte complexes (COCs) were collected and washed in Tyrode's lactate-Hepes containing $0.1 \%(\mathrm{w} / \mathrm{v})$ polyvinyl alcohol (PVA). Oocytes with several layers of cumulus cells were selected and washed three times in TCM-199 (GIBCO) supplemented with 0.1\% PVA (w/v), $3.05 \mathrm{mM}$ D-glucose, $0.91 \mathrm{mM}$ sodium pyruvate, $0.57 \mathrm{mM}$ cysteine, $0.5 \mu \mathrm{g} / \mathrm{mL}$ luteinizing hormone, $0.5 \mu \mathrm{g} / \mathrm{mL}$ follicle stimulating hormone, $10 \mathrm{ng} / \mathrm{mL}$ epidermal growth factor, $10 \%$ porcine follicular fluid ( $\mathrm{pFF}), 75 \mu \mathrm{g} / \mathrm{mL}$ penicillin $\mathrm{G}$, and $50 \mu \mathrm{g} / \mathrm{mL}$ streptomycin (maturation medium). For in vitro maturation, 50 COCs were transferred into $500 \mu \mathrm{L}$ of maturation medium in a four-well dish (Nunc, Roskilde, Denmark). The oocytes were matured for $40 \mathrm{~h}$ at $38.5^{\circ} \mathrm{C}$ under $5 \% \mathrm{CO}_{2}$ in air. Somatic cell nuclear transfer was performed as follows (Kwon et al., 2017). Briefly, matured oocytes were enucleated by aspirating the first polar body and metaphase II chromosomes and a small amount of surrounding cytoplasm in manipulation medium supplemented with $5 \mu \mathrm{g} / \mathrm{mL}$ cytochalasin B. The freshly-thawed donor cells treated with Roscovitine were inserted into perivitelline space. The karyoplast-cytoplast complexes were placed into $0.2-\mathrm{mm}$ diameter wire electrodes $(1 \mathrm{~mm}$ apart) of a fusion chamber covered with $0.3 \mathrm{M}$ mannitol solution containing $0.1 \mathrm{mM} \mathrm{MgSO} 4,1.0 \mathrm{mM} \mathrm{CaCl}_{2}$ and $0.5 \mathrm{mM}$ Hepes. For reconstructions, two DC pulses (1-sec interval) of $1.5 \mathrm{kV} / \mathrm{cm}$ were applied for $30 \mu \mathrm{s}$ using an Electro-Cell fusion (Fujihira Industry, Japan). Immediately 
after confirmation of fusion using a stereoscope, the reconstructed embryos were transferred into both oviducts of the surrogate (Landrace) on the same day or 1 day after the onset of estrus. Pregnancy was diagnosed on day 28 after ET and then was checked regularly every week by ultrasound examination. The TG cloned piglets were delivered by Caesarean section.

\section{Confirmation of transgenic pig}

Genomic DNA (gDNA) was isolated from the tails of the cloned piglets. gDNA was used for transgene insertion by polymerase chain reaction (PCR) with specific primer sets using upstream primer 5'-TATCGCGATCTAGAAAC ACACTGCAAGTCC-3' and downstream primer 5'-ATAA GCTTAGGAAAGAGCCGAGGACCGCCT-3' which contain Nru I and Hind III site, respectively (Fig. 2A). The PCR cycle was as follows: initial denaturation at $95^{\circ} \mathrm{C}$ for $5 \mathrm{~min} ; 30$ cycles of $94^{\circ} \mathrm{C}$ for $30 \mathrm{~s}$, the optimized annealing temperature for $30 \mathrm{~s}$, and $72^{\circ} \mathrm{C}$ for $30 \mathrm{~s}$; followed by a final extension at $72^{\circ} \mathrm{C}$ for $5 \mathrm{~min}$.

\section{RESULTS}

A summary of the pregnancy and delivery rate of hCD73-pig was described in Table 1. The mean number of embryos transferred was $127 \pm 18.9$ of cloned embryos and $126 \pm 18.7$ of parthenogenetic embryos, respectively. Among
18 surrogates, 8 were pregnant (44\%) in early pregnancy period and 3 were maintained to full term $(16 \%)$. The total number of delivered cloned piglets were 10 ( 2 alive, 7 mummy, and 1 died after birth) (Fig. 1A). The recipientbased individual cloning efficiency was range from $0.7 \%$ to $2.2 \%$ (Table 2). Produced transgenic pigs were confirmed by genomic PCR. All of the cloned pigs were confirmed as the hCD73 TG pig (Fig. 1B). And also the two hCD73 TG cloned pigs had normal reproductive ability.

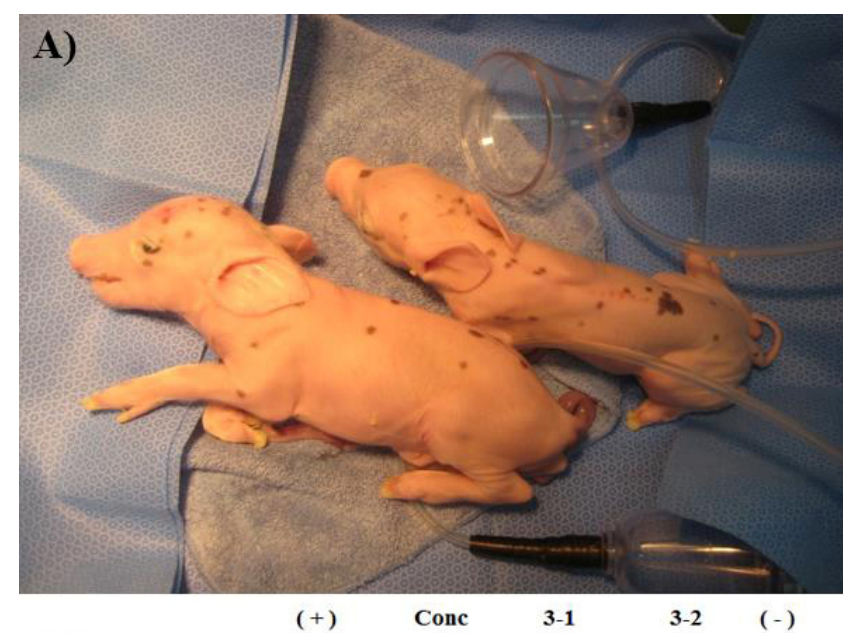

\section{B)}

$1.0 \mathrm{~kb} \rightarrow$ $0.5 \mathrm{~kb} \rightarrow$

Fig. 1. Production and confirmation of cloned hCD73 piglets. A) Productions of hCD73 transgenic cloned piglets originated from $\mathrm{MGH}$ miniature pig. B) Confirmation of pICAM-CD73 vector.

Table 1. Productivity of hCD73 transgenic cloned piglets

\begin{tabular}{|c|c|c|c|c|c|c|}
\hline & \multicolumn{2}{|c|}{ No. of embryos transferred } & \multicolumn{2}{|c|}{ No. of surrogates } & \multicolumn{2}{|c|}{ No. of piglets } \\
\hline & NT & Parthenotes & Pregnancy & Delivery* & Live & Dead $^{* *}$ \\
\hline hCD73 & $127 \pm 18.9$ & $126 \pm 18.7$ & $8 / 18$ & $3 / 18$ & 3 & 7 \\
\hline
\end{tabular}

Data were expressed as mean \pm SD.

* Included spontaneously abortion.

${ }^{* *}$ Included miscarriage piglets at 74 days after embryo transfer. 
Table 2. Full term development of hCD73 TG cloned piglets

\begin{tabular}{|c|c|c|c|c|c|c|}
\hline \multirow{2}{*}{ Surrogates } & \multirow{2}{*}{ Cell types } & \multirow{2}{*}{$\begin{array}{l}\text { No. of embryos } \\
\text { transferred }\end{array}$} & \multirow{2}{*}{$\begin{array}{l}\text { Pregnancy } \\
\text { period }\end{array}$} & \multirow{2}{*}{$\begin{array}{l}\text { Delivery } \\
\text { types }\end{array}$} & \multicolumn{2}{|c|}{ No. of piglets } \\
\hline & & & & & At birth & $>6$ months \\
\hline 1 & CD73(35-1) & 138 & & & & \\
\hline 2 & CD73(17-1) & 149 & & & & \\
\hline 3 & CD73(20-1) & 130 & & & & \\
\hline 4 & CD73(41-1) & 131 & & & & \\
\hline 5 & CD73(10-1) & 121 & & & & \\
\hline 6 & CD73(1-1) & 139 & & & & \\
\hline 7 & CD73(2-1) & 122 & & & & \\
\hline 8 & CD73(4-1) & 132 & & & & \\
\hline 9 & CD73(4-1) & 153 & & & & \\
\hline 10 & CD73(12-1) & 142 & 116 & C-sec & $\begin{array}{l}\text { Alive }(\times 1,524 \mathrm{~g}) \\
\text { Mummy }(\times 4)\end{array}$ & \\
\hline 11 & CD73(15-1) & 127 & 74 & & Miscarriage $(\times 3)$ & \\
\hline 12 & CD73(18-1) & 131 & & & & \\
\hline 13 & CD73(1-2) & 135 & & & & \\
\hline 14 & CD73(2-2) & 128 & & & & \\
\hline 15 & CD73(4-2) & 138 & & & & \\
\hline 16 & CD73(12-2) & 90 & & & & \\
\hline 17 & CD73(15-2) & 90 & 115 & C-sec & $\begin{array}{c}\text { Alive } \\
(\times 2,608 \& 668 \mathrm{~g})\end{array}$ & 2 \\
\hline 18 & CD73(18-2) & 90 & & & & \\
\hline
\end{tabular}

They mated with wild type (WT) MGH female sows and produced totally 16 piglets. Among them, 6 piglets were identified as hCD73 TG pigs (Table 3) (Fig. 2B).

\section{DISCUSSION}

Xenotransplantation results in hyperacute rejection mediated by the interaction with antibodies against $\alpha$-Gal residues on cell surface glycoproteins of pig cells. The problem of hyperacute rejection has been overcome by homozygous GT KO pigs (Phelps et al., 2003; Kolber-Simonds et al., 2004; Nottle et al., 2007; Fujimura et al., 2008; Li et al., 2013). Although the transplantation of kidney or heart from a GT KO pig into an immunosuppressed primate could prolong the xenograft survival, the xenograft finally fails because of thrombotic microangiopathy that may be form of delayed immune-mediated rejection (Chen et al., 2005; Kuwaki et al., 2005; Lin et al., 2010).

Extracellular nucleotides and its derivatives directly or indirectly regulate many processes such as thrombosis or inflammation, vascular tone, and iron transport, via cell surface purinergic receptors (Arulkumaran et al., 2013; Zimmermann et al., 1996). However, the final effect of these signaling mechanisms is depended on the conversion of these nucleotides mediated by the cascade of ectoenzymes i.e. CD39 and CD73. These activities lead to the con- 
Table 3. Production of hCD73 TG piglets by natural mating

\begin{tabular}{|c|c|c|c|}
\hline Paternal( (ْ) & Maternal $($ $(+)$ & \multicolumn{2}{|c|}{ Piglets } \\
\hline \multirow{10}{*}{$\begin{array}{c}\text { CD73 } \\
3-1(ð)\end{array}$} & \multirow{5}{*}{$5-1(\mathrm{WT})$} & 18-1(ㅇ) & TG \\
\hline & & 18-2(우) & TG \\
\hline & & 18-3(우) & \\
\hline & & 18-4(ㅇ) & \\
\hline & & $18-5(\overbrace{}^{\lambda})$ & \\
\hline & \multirow{5}{*}{ 6-2(WT) } & 19-1(P) & TG \\
\hline & & 19-2(우) & \\
\hline & & $19-3(\overbrace{}^{\lambda})$ & \\
\hline & & $19-4($ Љ) & TG \\
\hline & & $19-5($ Љ) & TG \\
\hline \multirow{6}{*}{$\begin{array}{l}\text { CD73 } \\
3-2(ð))\end{array}$} & \multirow{6}{*}{$6-5(\mathrm{WT})$} & 21-1(우) & \\
\hline & & 21-2(ㅇ) & TG \\
\hline & & 21-3(우) & \\
\hline & & $21-4\left(0^{\lambda}\right)$ & \\
\hline & & $21-5\left(\partial^{\lambda}\right)$ & \\
\hline & & $21-6\left(0^{\lambda}\right)$ & \\
\hline
\end{tabular}

A)

plCAM-2 promoter hCD73/bGH-pA Hygro $^{R}$
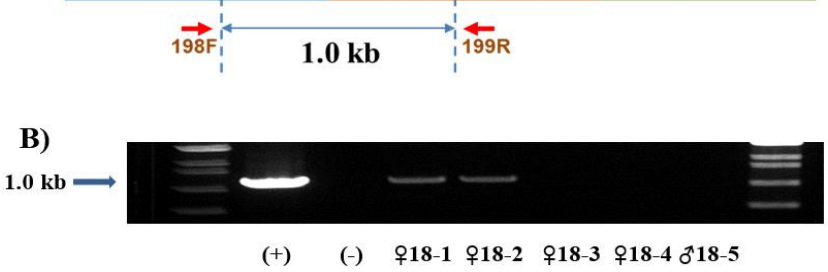

Fig. 2. PCR analysis to confirm insertion of pICAMCD73 vector in hCD73 transgenic progenies. A) The primer sites to validate integration of the pIcma2-CD73 vector were shown as $198 \mathrm{~F}$ and 199R. The diagram was modified from Oh et al. (2016). B) The confirmation of hCD73 TG piglets born between hCD73 cloned pigs and MGH miniature pig. version of pro-inflammatory adenosine triphosphate (ATP) and adenosine diphosphate (ADP) to adenosine monophosphate and adenosine, which released from stressed or damaged cells into extracellular space. This change of ATP-dependent pro-inflammatory state into anti-inflammatory environment is mediated by adenosine (Arul-kumaran et al., 2013; Bauerle et al., 2011). It was reported that immune rejection in xenotransplantation experiments causes the loss of activity of porcine CD39 and CD73 resulting in a reduced capacity to convert pro-inflammatory and proaggregatory extracellular nucleotides into adenosine (Khalpey et al., 2005; Cowan 2007). Overexpression of both human CD39 and CD73 could enhance ATP and ADP breakdown and adenosine production in porcine xenotransplantation model (Cooper et al., 2012).

Wheeler et al. (2012) demonstrated that hCD39 transgene expression reduces myocardial injury in a porcine model of myocardial acute ischemia-reperfusion injury. In 2015, Iwase et al reported that transgenic GT KO pigs expressing complement regulatory protein (CD46) for inhibiting acute and vascular rejection, thrombomodulin and endothelial protein $\mathrm{C}$ receptor for repressing the blood clotting factors have been produced. Choi et al. (2016) produced the heterozygous GT KO transgenic miniature pigs expressing human CD39 for repressing the immune rejection responses that are common following by pig xenografts. Also, it has been reported that GT KO pigs heart overexpressing CD46 and thrombomodulin were transplanted into baboons and survived up to 945 days (Mohiuddin et al., 2016).

However, there has been no report on pigs that introduced hCD73, so the need for the development of transgenic pigs is being raised. Considering the function of sequentially degrading nucleic acids with CD39, it is assumed that the same effect will be obtained in transgenic pigs overexpressing CD73. However, it is not yet known whether adenosine produced by overexpressing CD39 or CD73 would effectively inhibit blood clotting when pig 
organs were transplanted into monkeys.

In this study, we successfully produced two healthy hCD73 transgenic cloned piglets and they have normal reproductive ability for next generation. In future, GT $\mathrm{KO} /$ CD46/CD73 hybrid transgenic pig can be produced by crossing hCD73 positive and GT KO/CD46 TG pig and the TG pigs will be more effective model to use in research for controlling hyperacute and acute vascular rejection after xenotransplantation.

\section{ACKNOWLEDGEMENTS}

This work was carried out with the support of "Animal Science \& Technology Development (Project No. PJ01226502)" from Rural Development Administration, Republic of Korea. This study was supported by 2017 Postdoctoral Fellowship Program of National Institute of Animal Science, Rural Development Administration, Republic of Korea.

\section{REFERENCES}

Arulkumaran N, Turner CM, Sixma ML, Singer M, Unwin

R, Tam FW (2013) Purinergic signaling in inflammato-

ry renal disease. Front Physiol 4:1-7.

Bauerle JD, Grenz A, Kim JH, Lee HT, Eltzschig HK (2011)

Adenosine generation and signaling during acute kidney injury. J Am Soc Nephrol 22:14-20.

Chen G, Qian H, Starzl T, Sun H, Garcia B, Wang X, Wise Y, Liu Y, Xiang Y, Copeman L, Liu W, Jevnikar A, Wall W, Cooper DK, Murase N, Dai Y, Wang W, Xiong Y, White DJ, Zhong R (2005) Acute rejection is associated with antibodies to non-Gal antigens in baboons using Gal-knockout pig kidneys. Nat Med 11:12951298.

Choi K, Shim J, Ko N, Eom H, Kim J, Lee JW, Jin DI, Kim H (2017) Production of heterozygous alpha 1,3galactosyltransferase (GGTA1) knock-out transgenic miniature pigs expressing human CD39. Transgenic Res 26:209-224.

Cooper DK, Ekser B, Burlak C, Ezzelarab M, Hara H, Paris L, Tector AJ, Phelps C, Azimzadeh AM, Ayares D, Robson SC, Pierson RN 3rd (2012) Clinical lung xenotransplantation--what donor genetic modifications may be necessary? Xenotransplantation 19:144-158.

Cowan PJ, d'Apice AJ (2009) Complement activation and coagulation in xenotransplantation. Immunol Cell Biol 87:203-208

Cowan PJ (2007) Coagulation and the xenograft endothelium. Xenotransplantation 14: 7-12.

Crikis S, Cowan PJ, d'Apice AJ (2006) Intravascular thrombosis in discordant xenotransplantation. Transplantation 82: 1119-1123.

Daval JL, Nehlig A, Nicolas F (1991) Physiological and pharmacological properties of adenosine: therapeutic implications. Life Sci 49:1435-1453.

Delikouras A, Fairbanks LD, Simmonds AH, Lechler RI, Dorling A (2003) Endothelial cell cytoprotection induced in vitro by allo- or xenoreactive antibodies is mediated by signaling through adenosine $\mathrm{A} 2$ receptors. Eur J Immunol 33:3127-3135.

Ekser B, Ezzelarab M, Hara H, van der Windt DJ, Wijkstrom M, Bottino R, Trucco M, Cooper DK (2012) Clinical xenotransplantation: the next medical revolution? Lancet 379:672-683.

Fujimura T, Takahagi Y, Shigehisa T, Nagashima H, Miyagawa S, Shirakura R, Murakami H (2008) Production of alpha 1,3-galactosyltransferase gene-deficient pigs by somatic cell nuclear transfer: a novel selection method for gal alpha 1,3-Gal antigen-deficient cells. Mol Reprod Dev 75:1372-1378.

Higginbotham L, Mathews D, Stephenson A, Breeden1 C, Larsen1 CP, Ford ML, Newell KA, Tector J, Adams AB (2015) Long-term survival of pig-to-primate renal xenotransplant using costimulation-blockade immunosuppression. In: Transplantation pp s72-s73. 
Houser SL, Kuwaki K, Knosalla C, Dor FJ, Gollackner B, Cheng J, Shimizu A, Schuurman HJ, Cooper DK (2004) Thrombotic microangiopathy and graft arteriopathy in pig hearts following transplantation into baboons. Xenotransplantation 11:416-425.

Hwang IS, Kwon DJ, Oh KB, Ock SA, Chung HJ, Cho IC, Lee JW, Im GS, Hwang S (2015) Production of cloned Korean native pig by somatic cell nuclear transfer. Dev Reprod 19:79-84.

Iwase H, Liu H, Wijkstrom M, Zhou H, Singh J, Hara H, Ezzelarab M, Long C, Klein E, Wagner R, Phelps C, Ayares D, Shapiro R, Humar A, Cooper DK (2015) Pig kidney graft survival in a baboon for 136 days: longest lifesupporting organ graft survival to date. Xenotransplantation 22:302-309.

Khalpey Z, Yuen AH, Kalsi KK, Kochan Z, Karbowska J, Slominska EM, Forni M, Macherini M, Bacci ML, Batten P, Lavitrano M, Yacoub MH, Smolenski RT (2005) Loss of ecto-50 nucleotidase from porcine endothelial cells after exposure to human blood: implications for xenotransplantation. Biochim Biophys Acta 1741:191-198.

Kim H, Chee HK, Yang J, Hwang S, Han KH, Kang J, Park JH, Kim JS, Lee SJ, Ock SA, Park MH, Park KS, Lee BC, Cho K, Noh J, Park W, Yun IJ, Ahn C (2013) Outcomes of alpha 1,3-GT-knockout porcine heart transplants into a preclinical nonhuman primate model. Transplant Proc 45:3085-3091.

Kolber-Simonds D, Lai L, Watt SR, Denaro M, Arn S, Augenstein ML, Betthauser J, Carter DB, Greenstein JL, Hao Y, Im GS, Liu Z, Mell GD, Murphy CN, Park KW, Rieke A, Ryan DJ, Sachs DH, Forsberg EJ, Prather RS, Hawley RJ (2004) Production of alpha-1,3-galactosyltransferase null pigs by means of nuclear transfer with fibroblasts bearing loss of heterozygosity mutations. Proc Natl Acad Sci USA 101:7335-7340.

Kuwaki K, Tseng YL, Dor FJ, Shimizu A, Houser SL, Sanderson TM, Lancos CJ, Prabharasuth DD, Cheng J,
Moran K, Hisashi Y, Mueller N, Yamada K, Greenstein JL, Hawley RJ, Patience C, Awwad M, Fishman JA, Robson SC, Schuurman HJ, Sachs DH, Cooper DK (2005) Heart transplantation in baboons using alpha 1, 3-galactosyltransferase gene-knockout pigs as donors: initial experience. Nat Med 11:29-31.

Kwon DJ, Kim DW, Hwang IS, Kim DE, Kim HJ, Kim JS, Lee K, Im GS, Lee JW, Hwang S (2017) Generation of a -1,3-galactosyltransferase knocked-out transgenic cloned pigs with knocked-in five human genes. Transgenic Res 26:153-163.

Lambrigts D, Sachs DH, Cooper DK (1998) Discordant organ xenotransplantation in primates: world experience and current status. Transplantation 66:547-561.

Lee HJ, Lee BC, Kim YH, Paik NW, Rho HM (2011) Characterization of transgenic pigs that express human decay accelerating factor and cell membrane-tethered human tissue factor pathway inhibitor. Reprod Domest Anim 46:325-332.

Li P, Estrada JL, Burlak C, Tector AJ (2013) Biallelic knockout of the alpha-1,3 galactosyltransferase gene in porcine liver-derived cells using zinc finger nucleases. J Surg Res 181:e39-45.

Lin CC, Cooper DK, Dorling A (2009) Coagulation dysregulation as a barrier to xenotransplantation in the primate. Transpl Immunol 21:75-80.

Lin CC, Ezzelarab M, Shapiro R, Ekser B, Long C, Hara H, Echeverri G, Torres C, Watanabe H, Ayares D, Dorling A, Cooper DK (2010) Recipient tissue factor expression is associated with consumptive coagulopathy in pig-to-primate kidney xenotransplantation. Am J Transplant 10:1556-1568.

McGregor CG, Teotia SS, Byrne GW, Michaels MG, Risdahl JM, Schirmer JM, Tazelaar HD, Walker RC, Logan JS (2004) Cardiac xenotransplantation: progress toward the clinic. Transplantation 78:1569-1575.

Mohiuddin MM, Singh AK, Corcoran PC, Thomas Iii ML, Clark T, Lewis BG, Hoyt RF, Eckhaus M, Pierson Iii 
RN, Belli AJ, Wolf E, Klymiuk N, Phelps C, Reimann KA, Ayares D, Horvath KA (2016) Chimeric 2C10R4 anti-CD40 antibody therapy is critical for long-term survival of GTKO.hCD46.hTBM pig-to-primate cardiac xenograft. Nat Commun 7:1-10.

Nottle MB, Beebe LF, Harrison SJ, McIlfatrick SM, Ashman RJ, O'Connell PJ, Salvaris EJ, Fisicaro N, Pommey S, Cowan PJ, d'Apice AJ (2007) Production of homozygous alpha-1,3-galactosyltransferase knockout pigs by breeding and somatic cell nuclear transfer. Xenotransplantation 14:339-344.

Oh KB, Lee H, Hwang S, Ock SA, Chung HJ, Byun SJ, Lee P, Im GS (2016) Production of porcine fibroblasts carrying a vector enforced specific expression of CD73 to endothelial cells. J Emb Trans 31:161-168.

Phelps CJ, Koike C, Vaught TD, Boone J, Wells KD, Chen SH, Ball S, Specht SM, Polejaeva IA, Monahan JA, Jobst PM, Sharma SB, Lamborn AE, Garst AS, Moore M, Demetris AJ, Rudert WA, Bottino R, Bertera S, Trucco M, Starzl TE, Dai Y, Ayares DL (2003) Production of alpha 1,3-galactosyltransferase-deficient pigs. Science 299:411-414.

Rocha PN, Plumb TJ, Crowley SD, Coffman TM (2003) Effector mechanisms in transplant rejection. Immunol Rev 196:51-64.

Shimizu A, Hisashi Y, Kuwaki K, Tseng YL, Dor FJ, Houser SL, Robson SC, Schuurman HJ, Cooper DK,
Sachs DH, Yamada K, Colvin RB (2008) Thrombotic microangiopathy associated with humoral rejection of cardiac xenografts from alpha1,3-galactosyltransferase gene-knockout pigs in baboons. Am J Pathol 172:14711481.

Sitkovsky MV, Lukashev D, Apasov S, Kojima H, Koshiba M, Caldwell C, Ohta A, Thiel M (2004) Physiological control of immune response and inflammatory tissue damage by hypoxia-inducible factors and adenosine A2A receptors. Annu Rev Immunol 22:657-682.

Tseng YL, Kuwaki K, Dor FJ, Shimizu A, Houser S, Hisashi Y, Yamada K, Robson SC, Awwad M, Schuurman HJ, Sachs DH, Cooper DK (2005) alpha 1,3Galactosyltransferase gene-knockout pig heart transplantation in baboons with survival approaching 6 months. Transplantation 80:1493-1500.

Wheeler DG, Joseph ME, Mahamud SD, Aurand WL, Mohler PJ, Pompili VJ, Dwyer KM, Nottle MB, Harrison SJ, d'Apice AJ, Robson SC, Cowan PJ, Gumina RJ (2012) Transgenic swine: expression of human CD39 protects against myocardial injury. J Mol Cell Cardiol 52:958-961.

Zhang B, Zhang A, Zhao Y (2008) Platelet aggregation and thrombosis in xenotransplantation between pigs and humans. Thromb Res 121:433-441.

Zimmermann H (1996) Extracellular purine metabolism. Drug Dev Res 39:337-352. 